\title{
Observations on the genus Amaurochaete (Myxomycetes), and a European record of $\mathrm{A}$. trechispora
}

\author{
UNO H. ELIASSON
}

\begin{abstract}
ELIASSON, U. H. 2000: Observations on the genus Amaurochaete (Myxomycetes), and a European record of A. trechispora. - Karstenia 40: 31-38. Helsinki. ISSN 0435-3402.

The borderlines between the genera Amaurochaete, Symphytocarpus and Stemonitis pose taxonomic and nomenclatural questions due to the limited amount of type material and the variability of the species involved. Details in spore ornamentation lend strong support to the notion that Amaurochaete ferruginea and Stemonitis splendens var. flaccida are conspecific. The ornamentation consists of evenly distributed short-cylindrical processes with rounded tips, and the wall of the spore body has numerous pores 25 $30 \mathrm{~nm}$ wide. Amaurochaete atra, A. tubulina, and A. comata all appear to be more or less restricted to coniferous wood as a substratum. The vast majority of the first two species have been found on wood and bark of Pinus, whereas the much rarer $A$. comata so far has been recorded on Abies, Picea, and Tsuga. Amaurochaete trechispora is an oddity in the genus, differing in its reticulate-ornamented spores and growing on Sphagnum mats in bogs. A specimen from Sweden is the first record of this species outside North America. A specimen from France with spore ornamentation consisting of pillarshaped papillae with swollen tips may represent an undescribed species of Amaurochaete.
\end{abstract}

Key words: Amaurochaete, Stemonitales, Symphytocarpus

Uno H. Eliasson, Botanical Institute, Göteborg University, Box 461, SE 40530 Göteborg, Sweden

\section{Introduction}

Amaurochaete Rost. is a small genus of the order Stemonitales, characterized by comparatively large, fragile, more or less pulvinate aethalioid fructifications with evanescent peridium and a dark spore mass. If the somewhat different taxon A. ferruginea T.Macbr. \& G.W.Martin is exempted, the genus comprises four currently recognized species, inhabiting different ecological niches (Eliasson 1977). Nowhere abundant, the genus has so far been found only in the northern hemisphere and has not been recorded in the tropics. Beetles of the genus Anisotoma are very often associated with various stages in the life cycle of the myxomycete and are commonly found in mature fructifications. The beetles become powdered with spores and are probably the most important dispersal agent for Amaurochaete.

\section{Observations on different species}

Amaurochaete atra (Alb. \& Schwein.) Rostaf. and $\boldsymbol{A}$. tubulina (Alb. \& Schwein.) T.Macbr.

The two most wide-spread and well-known species, Amaurochaete atra and A. tubulina, appear to have rather similar ecological requirements. Both species grow on wood and exhibit a preference for undecayed Pinus wood. Plasmodia occur within the wood and move out through fissures or insect tunnels to form fructifications on the surface of the wood or bark (Eliasson 1977). Movement onto the bark surface appears to be possible through pores in the vascular system. Plasmodia and fructifications may sometimes form on wood that is very hard and has been stored under dry conditions for prolonged periods of time. Both species seem to be more or less confined to coniferous wood, with Pinus by 
far the most common substratum (Eliasson 1977, 1981, Krieglsteiner 1993). Apart from Pinus, there are literature records of $A$. atra on Abies and Picea in Germany (Krieglsteiner \& Krieglsteiner 1990, Luschka 1992), and of A. tubulina on Picea in Norway (Johannesen 1982). Härkönen's (1989) record of Amaurochete tubulina on a "stump in Betula forest" in Finland most probably refers to a stump of a coniferous tree (Härkönen, pers. comm.).

A specimen with a black spore mass was described by Nannenga-Bremekamp $(1974,1991)$ as

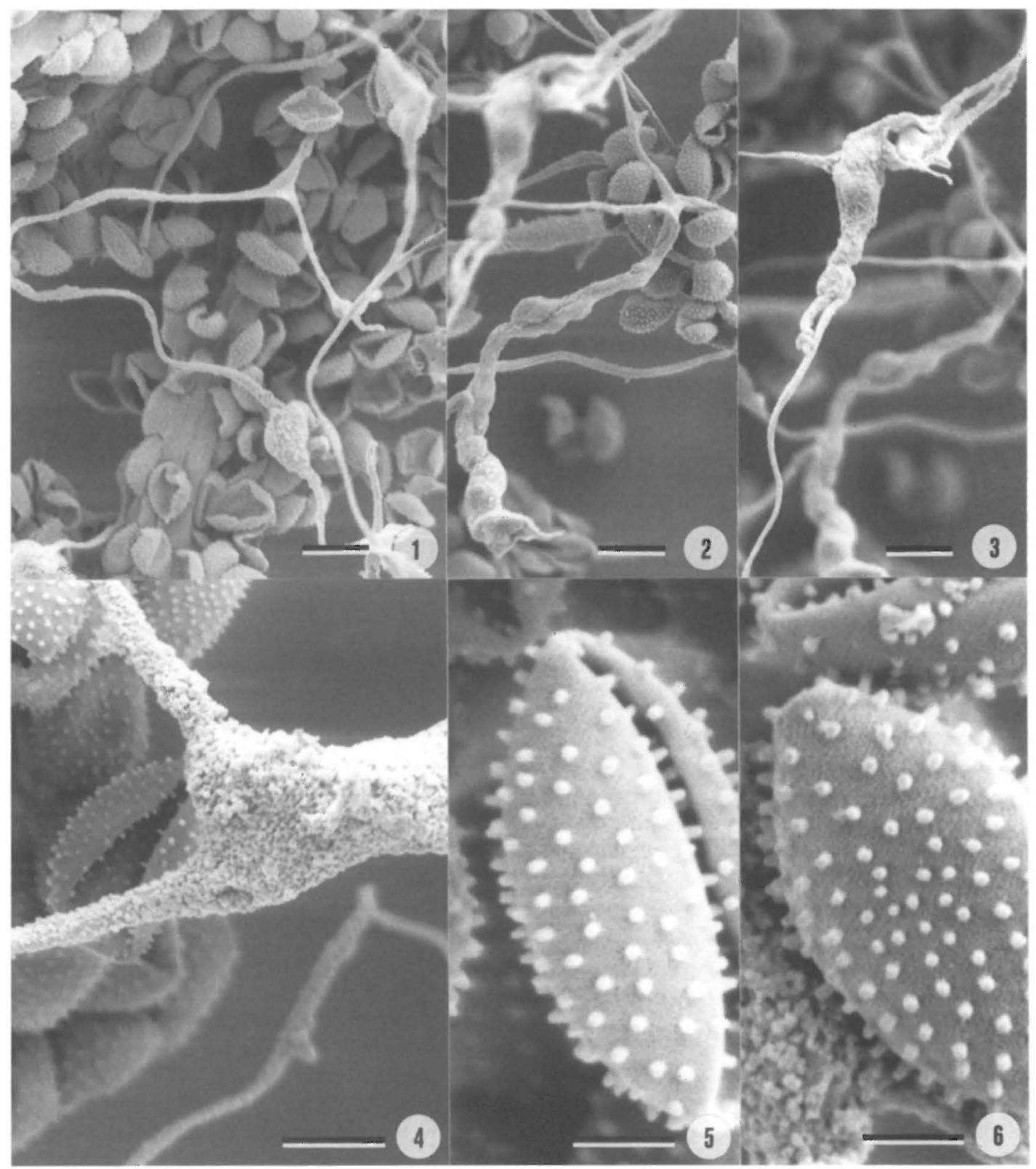

Figs. 1-6. Amaurochaete ferruginea (type specimen), SEMs. - 1-3: Part of capillitium and spore mass. 4: Part of capillitial branching with expansions. 5, 6: Collapsed spores showing details of ornamentation. - Bars: Figs. 1-3=10 $\mu \mathrm{m}$, Fig. $4=5 \mu \mathrm{m}$, Figs. 5, $6=2 \mu \mathrm{m}$. 
Amaurochaete sp. The spores were $13-15 \mu \mathrm{m}$ in diam., paler on one side and ornamented with scattered, rather prominent warts. It was found in close association with $A$. atra on a recently felled Pinus. From the description it appears to be close to A. tubulina.

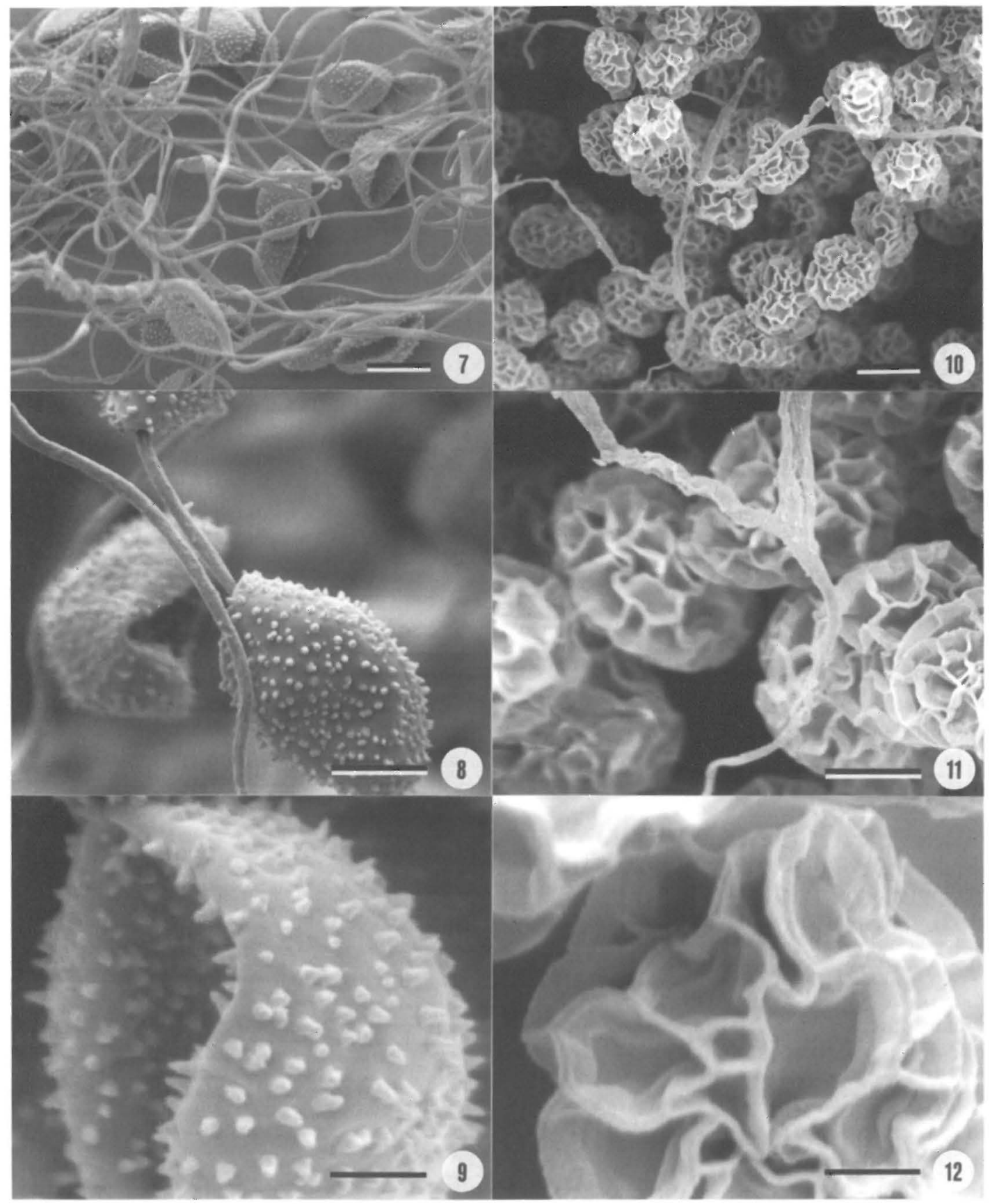

Figs. 7-12. Amaurochaete comata (Eliasson 2847) (Figs. 7-9) and A. trechispora (von Eichwald s. num.) (Figs. 1012), SEMs. $-7,8,10,11$ : Spores and capillitium. 9, 12: Collapsed spores showing details of ornamentation. - Bars: Figs. 7, $10=10 \mu \mathrm{m}$, Figs. $8,11=5 \mu \mathrm{m}$, Figs. $9,12=2 \mu \mathrm{m}$. 
A specimen on Quercus reported from California as "A. fuliginosa" (= A. atra) (Kowalski \& Curtis 1968) may deserve a closer study.

\section{A. comata G.Lister \& Brândză - Figs. 7-9}

Amaurochaete comata (Lister \& Brândză 1926) is characterized by an intricate circinate capillitium comprised throughout of slender flexuous threads (Figs. 7, 8). The spores are prominently warted, in the sole specimen studied by SEM with evenly distributed conical pointed projections $0.5-0.6 \mu \mathrm{m}$ long (Fig. 9). This rarely collected species has been recorded on Abies in Rumania and France (Lister \& Brândză 1926, Keller \& Candoussau 1973), on Picea in Sweden (Eliasson 1977) and Alaska (Farr 1982), on Tsuga in Japan (Yamamoto \& Nannenga-Bremekamp 1995, Yamamoto 1998), and on unspecified substratum in Germany (Neubert \& Baumann 1986, Krieglsteiner \& Krieglsteiner 1990) and California (Kowalski 1987).

A. ferruginea T.Macbr. \& G.W.Martin - Figs. 16,19

Amaurochaete ferruginea (Macbride \& Martin 1932) differs from other members of the genus in its brown spore mass and pale spores in transmitted light. The type specimen (U.S.A., California, Yosemite, Macbride 1A1438, BPI 749373) was received on loan from herbarium $B P I$ and studied by SEM (Figs. 1-6, 19). The specimen is poor, comprising three small pieces a few mm wide of an undetermined substratum with scanty fructification remains. The intricate capillitium arises from erect, irregular columella-like projections from the hypothallus and bears numerous irregular membranous expansions (Figs. 1-4). The spores tend to be slightly elliptic in outline, are mostly $8-9.5 \mu \mathrm{m}$ in diameter, but the size variation is large and many spores are irregular in shape, indicating aberrant development. They are almost colourless in transmitted light, distinctly ornamented with evenly distributed short-cylindrical processes ca. $0.35 \mu \mathrm{m}$ high with rounded tips (Figs. 5, 6). The wall appears to be thicker and darker along $60 \%$ or so of the periphery. It is difficult to say to what extent the striking paleness may be due to age or storage conditions.

Ing \& Nannenga-Bremekamp (1967) regarded Amaurochaete ferruginea as conspecific with Stemonitis splendens Rostaf. var. flaccida Lister, a variety separated on the basis of its lax capilli- tium and absence of a capillitial surface net (Lister 1894). The variety was raised to species level by Morgan (1894) as Comatricha flaccida (Lister) Morgan. The identity of the specimens Morgan had available when making this combination has been questioned (Martin \& Alexopoulos 1969, Nannenga-Bremekamp 1974, 1991), which, however, does not affect the formal validity of the combination. Although Morgan (1894) did not refer to vouchers or numbered specimens he made a clear reference to Lister's variety, saying that "Arthur Lister calls this Stemonitis splendens, var. flaccida".

A damaged and dried out microscopic slide of the original collection (Lister, Lyme, Regis, Dorset, VI.1893) of Stemonitis splendens var. flacc$i d a$ was kindly sent on loan from herbarium BM. The slide was not suitable for observing spore ornamentation, but at least some spores appear to be similar in shape and structure to those of Amaurochaete ferruginea. Although indications have been presented (Farr in Martin et al. 1983) that the two taxa may not be the same species, SEMs taken at BM of the type specimen (Figs. 17, 18) of Stemonitis splendens var. flaccida support the conspecificity. The type specimens of both taxa have spores of the same size and shape and the ornamentation is the same. In both taxa the wall of the spore body has numerous small pores 25-30 nm wide (Figs. 18, 19).

The genus Symphytocarpus Ing \& Nann.Bremek. (Ing \& Nannenga-Bremekamp 1967) was established to accommodate stemonitaceous taxa with more or less coalesced sporangia without a capillitial surface net. The type species, Symphytocarpus flaccidus (Lister) Ing \& Nann.Bremek., was based on Stemonitis splendens var. flaccida and accommodating also Amaurochaete ferruginea. Minor differences in the spore ornamentation of Symphytocarpus flaccidus (Figs. $15,16)$ may be regarded as representing infraspecific variation.

Symphytocarpus has been claimed to represent or at least include confluent or aberrant forms of Stemonitis (Farr in Martin et al. 1983) and there are different opinions on the justification of recognizing the genus. Until molecular support can be found for one view or the other, I prefer to maintain Symphytocarpus as a taxon, closely allied to Stemonitis. Molecular support is strongly needed for clarification of generic limits within the Stemonitales. 
From an ecological point of view, Symphytocarpus flaccidus resembles Amaurochaete atra and A. tubulina in that it most commonly grows on coniferous wood, preferably Pinus, with a dry and hard surface, for example dead, standing, decorticated trunks. It may appear on the same stump or decorticated trunk for several consecutive years (Eliasson 1981). Like the two species of Amaurochaete mentioned, it may also occur on planks, sometimes even painted, in buildings and garden furniture, indicating that stages of the myxomycete may remain alive within the wood for long periods of time. Although more rarely, it occasionally occurs on deciduous wood, such as Quercus (Ing 1964, as Comatricha flaccida).

A. trechispora T.Macbr. \& G.W.Martin - Figs. $10-12$

Amaurochaete trechispora (Macbride \& Martin 1932 ) is an oddity in the genus, differing in eco- logical as well as morphological features. Thus, it grows on Sphagnum mats in bogs and the spores are ornamented with high lists forming a large-meshed reticulum (Figs. 10-12). Although supposed by Hagelstein (1944) to represent merely a phase of Stemonitis trechispora (Torrend) T.Macbr. (= Symphytocarpus trechisporus (Torrend) Nann.-Bremek.), it is generally accepted as a different and well distinguished species (Ing \& Nannenga-Bremekamp 1967, Martin \& Alexopoulos 1969, Farr in Martin et al. 1983). Spores of $A$. trechispora are 12-14 $\mu \mathrm{m}$ in diam. (incl. ornamentation), the lists are $1.2-2 \mu \mathrm{m}$ high forming 4-5 meshes across the diameter of the spore. Spores of $S$. trechispora are 10-12 $\mu \mathrm{m}$ in diam., the lists are about $0.5 \mu \mathrm{m}$ high forming 8 10 meshes across the diameter of the spore.

Amaurochaete trechispora appears to be the rarest of the species in the genus. In the original description (Macbride \& Martin 1932) two spec-

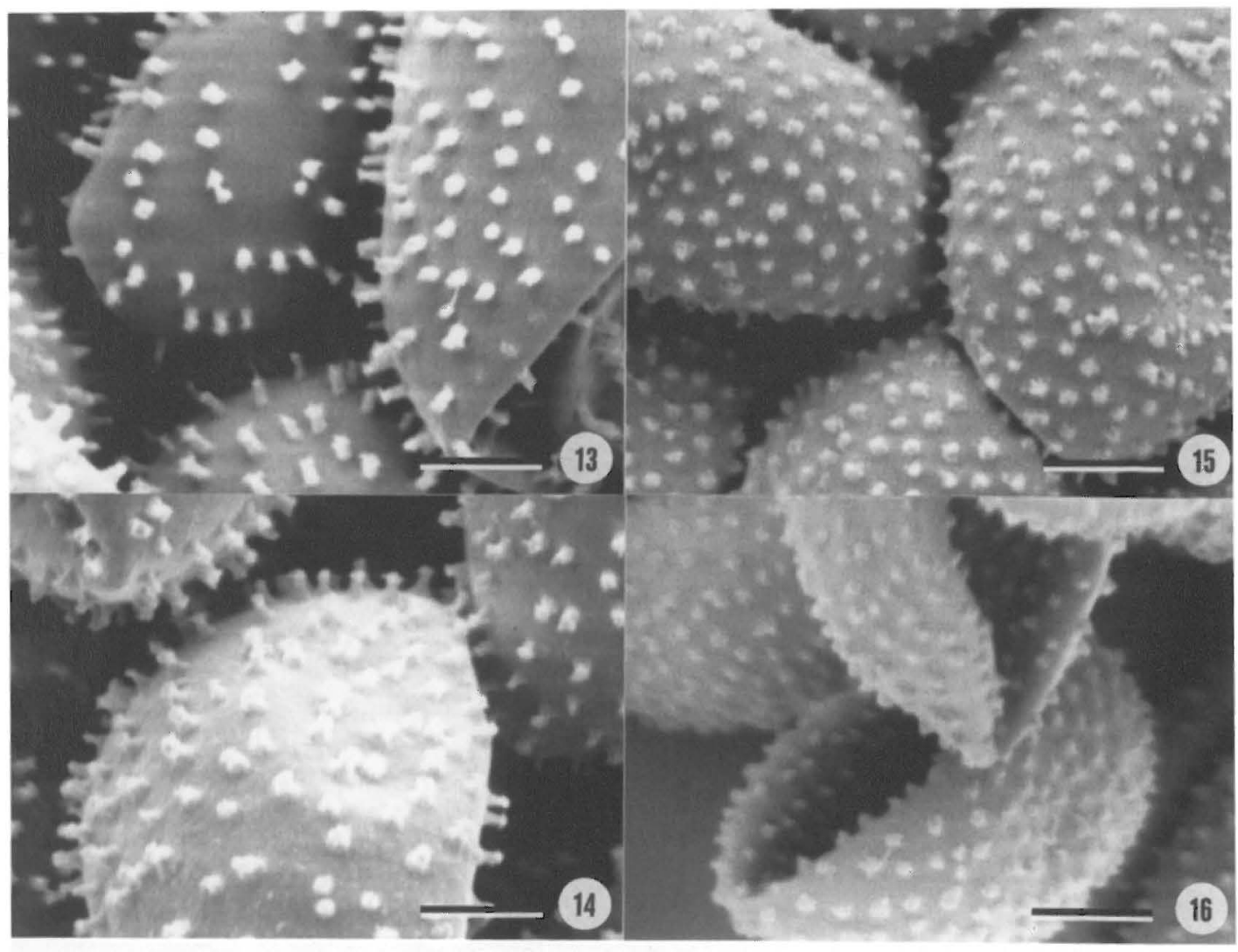

Figs. 13-16. Amaurochaete sp. (Meyer 19963)(Figs. 13, 14) and Symphytocarpus flaccidus (Eliasson 2832)(Figs. $15,16)$. SEMs showing details of spore ornamentation. - Bars: $2 \mu \mathrm{m}$. 
imens were cited, both from Ontario, Canada. Martin and Alexopoulos (1969) also cited the same species from Massachusetts, U.S.A. The specimen from Sweden (see the list of specimens examined) appears to be the first record outside North America. This European record is another

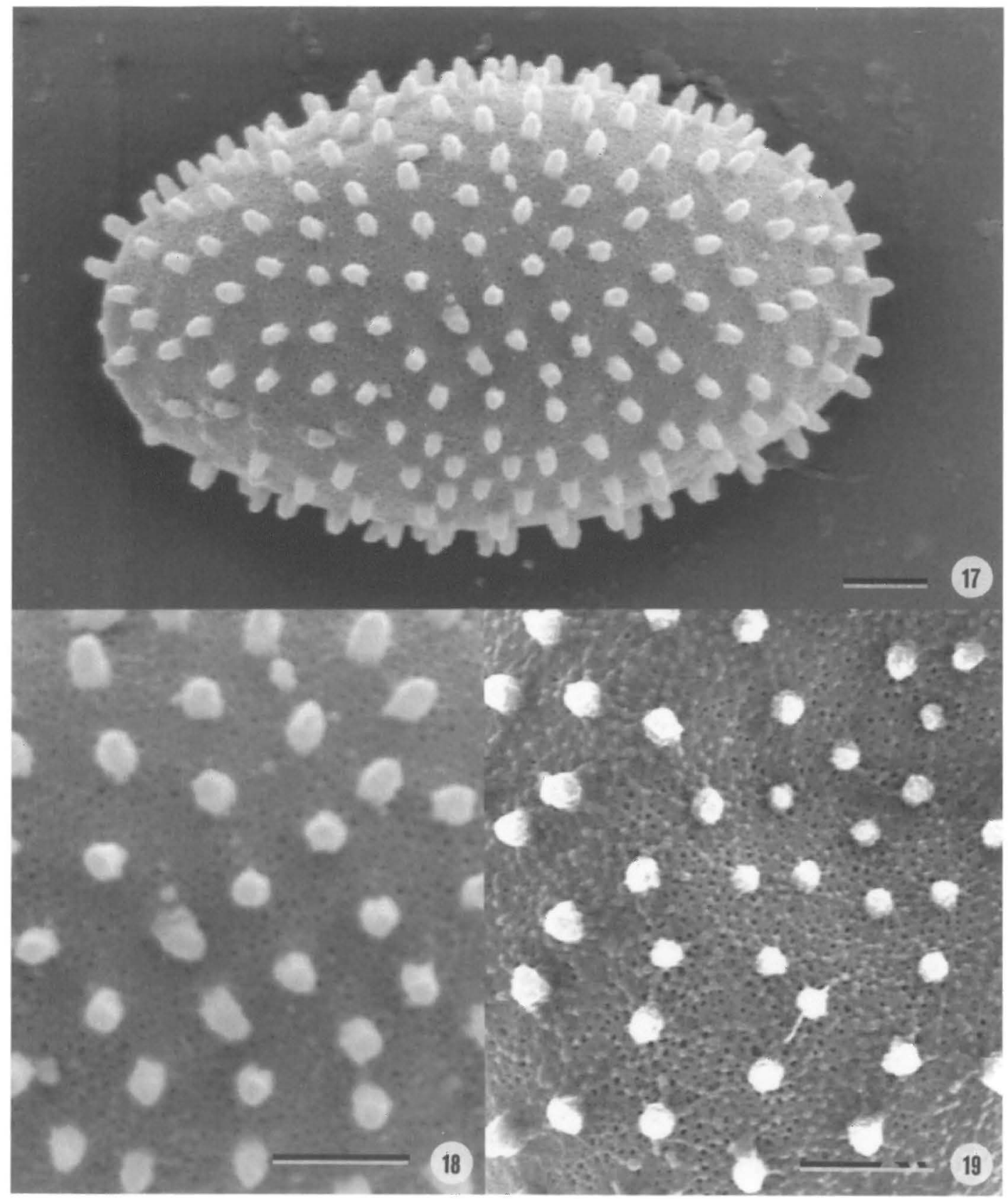

Figs. 17-19. Amaurochaete ferruginea. - 17,18: Spore of type specimen of Stemonitis splendens var. flaccida showing surface ornamentation and spore wall with pores. 19: Spore of type specimen of $A$. ferruginea showing similar ornamentation and pores. - Bars: $1 \mu \mathrm{m}$. - Figs. 17 and 18 published with due permission of the British Museum of Natural History (BM). 
example where a species of Myxomycetes known from only one part of the world may suddenly be found in a far distant region. Although $A$. trechispora forms large and conspicuous plasmodia and fructifications it may be overlooked in the field due to its odd substratum preferences. Without a closer examination the comparatively large plasmodium can probably be mistaken for the common species Fuligo septica and ignored.

Reticulate spores and its occurrence on Sphagnum mats is a combination of unusual features that Amaurochaete trechispora shares with Symphytocarpus trechisporus. Although the small-meshed spore reticulation of the latter species is strikingly different, lending support to the recognition of two different species, the rare combination of features might be indicative of a close taxonomic relationship (Ing 1999). S. trechisporus is known from North and South America, Europe and Japan.

\section{Amaurochaete sp.}

A specimen from France (Figs. 13, 14) collected on a living stem of Yucca (île Ste Marguerite, Sep 14, 1998 Meyer 19963, herb. Meyer) has a dark brown spore mass and prominent slender flexuous columella-like projections arising from the hypothallus. The projections and their branches gradually narrow, becoming extremely thin and dissipating towards apex. The spores are larger $(10.5-12 \mu \mathrm{m})$ than in the type specimen of Amaurochaete ferruginea, darker and spherical. The spore body, when seen by SEM, is ornamented with pillar-shaped papillae $0.35-0.45 \mu \mathrm{m}$ long which abruptly widen and end as a flattened or headlike tip (Figs. 13, 14). This species may represent an undescribed species. It is different from other species of Amaurochaete and does not match any of the species described in Symphytocarpus.

\section{Specimens examined in this study}

Amaurochaete comata G.Lister \& Brândzã: Sweden.Västergötland, Töllsjö parish, Bohult, on felled stem of Picea abies, 24.VII.1971 U. Eliasson 2847 (GB)

A. trechispora T.Macbr. \& G.W.Martin: Canada. Ontario, Nipissing Distr., Temagami Forest Reserve, Lake Temagami, N end of MacLean's Peninsula, on Sphagnum mat on floor of cold swamp, 6.VIII.1919 J.H. Faull 5135 (TRTC; type specimen); Lake Temaga$\mathrm{mi}$, Bear Island, on stem of herbaceous plant, 14.VIII.1931 H.S. Jackson 2460 (TRTC). Ontario,
Sturgeon Bay, Parry Sound Distr., on Sphagnum in bog, 27.VIII.1955 R.F. Cain 31739 (TRTC). U.S.A. Maine, Kittery Point, "found for a number of years ... in Sphagnum-Andromeda bog", 15.VIII.1905 R. Thaxter 7090 (TRTC). Sweden.Uppland, Upplands Väsby, Fresta, moist soil with tall grass near swamp, 11.VIII.1997 H. von Eichwald s. num. (GB). - A sample of a specimen from Luxemburg (Esch/Sûre, Kaundorf, on Polygonum persicaria in an emptied pond, 27.X.1991 G. Marson s. num., ex herb. M. Meyer 6888), may represent a second European record. The specimen is extremely poor, however, consisting of spores only and therefore doubtful.

Symphytocarpus flaccidus (Lister) Ing \& Nann.Bremek.: England. Lyme, Regis, Dorset, VI.1893 A. Lister (BM, type specimen of Stemonitis splendens var. flaccida Lister, slide seen). Sweden. Västergötland, Töllsjö parish, Bohult, 9.VII.1971 U. Eliasson 2832 (GB). U.S.A. California, Yosemite, Macbride 1 A1438 (BPI 749373, type specimen of Amaurochaete ferruginea T.Macbr. \& G.W.Martin).

Symphytocarpus trechisporus (Torrend) Nann.Bremek.: U.S.A. Maine, Kittery Point, Grassy bottom of dried out pond, VIII.1919 A. Thaxter (TRTC 2484). New York, Long Island, Albertson, "8-5-28" R. Hagelstein \& J.H. Rispaud 1302 (TRTC).

Acknowledgements: I am grateful to Curators of herbaria BM and BPI for loan of type material of Stemonitis splendens var. flaccida and Amaurochaete ferruginea, respectively. Dr. Len Ellis and Mr. Peter Stafford at BM were helpful in providing SEM pictures of type material of the first-named taxon. Dr. John C. Krug kindly lent several specimens from TRTC, including type material of A. trechispora. Mrs. Marianne Meyer sent specimens from France and Luxemburg for examination. Special thanks go to Mr. Hans von Eichwald for sending a sample of his collection of $A$. trechispora to be included in this study. Dr. Marja Härkönen provided information on some specimens from Finland. Mr. Yukinori Yamamoto translated some information on Amaurochaete from Japanese literature into English. Drs. Margit Fredriksson and Bengt R. Johansson assisted with the SEM work in Göteborg. Professor Harold W. Keller kindly read the manuscript and provided constructive criticism. I am grateful to all people mentioned for their help.

\section{References}

Eliasson, U. 1977: Ecological notes on Amaurochaete Rost. (Myxomycetes). - Bot. Notiser 129: 419-425.

Eliasson, U. 1981: Patterns of occurrence of myxomycetes in a spruce forest in South Sweden. - Holarctic Ecology 4: 20-31.

Farr, M. L. 1982: Notes on myxomycetes. III. - Mycologia 74: 339-343.

Hagelstein, R. 1944: The mycetozoa of North America. - Mineola, New York.

Härkönen, M. 1989: Thirteen taxa of myxomycetes new to Finland. - Karstenia 28: 93-99.

Ing, B. 1964: An unusual myxomycete in the London area. - London Naturalist 43: 16-17. 
Ing, B. 1999: The myxomycetes of Britain and Ireland. - The Richmond Publishing Co. Ltd. Slough, England. Ing, B. \& Nannenga-Bremekamp, N. E. 1967: Notes on myxomycetes XIII. Symphytocarpus nov. gen. stemonitacearum. - Proc. Kon. Ned. Akad. Wet. Ser. C, 70: $217-231$.

Johannesen, E. W. 1982: The myxomycetes of Norway. - Thesis Cand. Real., Botanical Institute, University of Oslo.

Keller, H. W. \& Candoussau, F. 1973: Quelques récoltes rares de myxomycètes en France. - Revue de Mycologie 38: 114-123.

Kowalski, D. T. 1987: New records of myxomycetes from California. VI. - Madroño 34: 48-56.

Kowalski, D. T. \& Curtis, D. H. 1968: New records of myxomycetes from California. III. - Madroño 19: 246-249.

Krieglsteiner, L. G. 1993: Verbreitung, Ökologie und Systematik der Myxomyceten im Raum Regensburg. - Libri Botanici 11. IHW-Verlag, Eching.

Krieglsteiner, L. G. \& Krieglsteiner, G. J. 1990: Die Pilze Ost- und Nord-Württembergs. Teil II: Myxomyceten. - Beiträge zur Kenntnis der Pilze Mitteleuropas, Bd 6: 119-229.

Lister, A. 1894: A monograph of the Mycetozoa. British Museum, London.

Lister, G. \& Brândză, M.1926: Amaurochaete comata. In: Lister, G., New species of Amaurochaete, and some other Mycetozoa. - Journ. Bot. 64: 225-227.
Luschka, N. 1992: Die Pilze des Nationalparks Bayerischer Wald im Bayrisch-Böhmischen Grenzgebirge (Böhmerwald). - Dissertation Naturw. Fakultät III, Universität Regensburg.

Macbride, T. H. \& Martin, G. W. 1932: Amaurochaete trechispora. - In: Martin, G. W., New species of slime molds. - Journ. Washington Acad. Sci. 22: 88-92.

Martin, G. W. \& Alexopoulos, C. J. 1969: The myxomycetes. - University of Iowa Press, Iowa.

Martin, G. W., Alexopoulos, C. J. \& Farr, M. L. 1983: The genera of myxomycetes. - University of Iowa Press, Iowa.

Morgan, A. P. 1894: The myxomycetes of the Miami Valley, Ohio. - J. Cinc. Soc. Nat. Hist. 3: 127-156, pl. 11,12 .

Nannenga-Bremekamp, N. E. 1974: De Nederlandse Myxomyceten. - Zutphen, Nederlands.

Nannenga-Bremekamp, N. E. 1991: A guide to temperate myxomycetes. - Biopress Limited, Bristol.

Neubert, H. \& Baumann, K. 1986: Myxomyceten aus der Bundesrepublik Deutschland III. Liste der bislang bekannten Arten. - Carolinea 44: 61-66.

Yamamoto, Y. 1998: The myxomycete biota of Japan. - Toyo Shorin Publishing Co., Ltd., Tokyo. (In Japanese.)

Yamamoto, Y. \& Nannenga-Bremekamp, N. E. 1995: Additions to the myxomycetes of Japan V. - Proc. Kon. Ned. Akad.. Wetensch. 98: 317-326. 